\title{
Analysis of the Pattern of Land Use Change in Calabar Municipality of Cross River State, Nigeria
}

\author{
Obongha, U. E. ${ }^{1^{*}}$, Agbor, E. A. ${ }^{2}$, and Upuji, Jennifer K. ${ }^{3}$ \\ ${ }^{1-3}$ Department of Urban and Regional Planning, Cross River University of Technology, Nigeria \\ *Corresponding Author
}

\begin{abstract}
This study is conducted in Calabar Municipality of Cross River State with the aim of analyzing the pattern of land use change within the LGA. The study was however, concerned with analyzing the impact posed by land use change on physical development and also considers the impact of population growth on land use change as well as factors which influence land use change. Both primary and secondary sources of data were employed in the survey design strategy of this research. While the analysis adopted the use of GIS intuition in map production for comparing land use changes from 2011 to 2020. The study recommended among others, strengthening of town planning authorities in order to monitor unpermitted land use changes/modifications and uncontrolled development.
\end{abstract}

Key Words: Dynamics, land use change, modification, population growth, physical development

\section{INTRODUCTION}

L and use involves both the manner in which the biophysical attributes of the land are manipulated and the intent underlying that manipulations as well as the purpose for which the land is put to (Braissoulis, 2009). It is the purpose for which human beings employ the land and its resources. Land use denotes the human employment of land. Land use change on the other hand, may involve either conversion from one type of use to another, that is, changes in the mix and pattern of land uses in an area or, modification of a certain type of Land Use. Modification of a particular land use which may involve changes in the intensity of its use as well as alterations of its characteristics qualities/ attributes - such as changes from low-income to high-income residential areas (the buildings remaining physically and qualitatively altered). Changes of suburban forests from their natural state to recreation sites such as stadia, pools, and housing estates and so on (Aluko, 2013). There is need for planning of land use patterns for better urban development.

The growth and development of urban areas is usually marked by a number of growth characteristics. These are either singular or in combination with other factors that brings about large population and settlements. For example, as cities grow and develop, they tend to involve a functional pattern of land uses. Some of these land uses that are common in Calabar Municipality include the following: residential, commercial, circulation, recreational, agricultural, institutional, cultural and industrial land uses and many more. Studies have shown that there is considerable change in the urban land use pattern of Calabar Municipality, which have deviated from the original planning schemes and however, culminated into irregularities on the land use pattern of study area.

Land use change occurs when a particular land is changed from the use that it was originally meant for, as a result of invasion and succession, economic rents, highest and best use and other factors that encompasses urbanization as a whole. Virtually all human activities requires land, from the large scale industrial complex, the supra metro-line, High way, rail line, the traditional market to the roadside cobblers and corner shops, all require land in varying dimensions (Agbola, 2004). It is against this background that this research is conducted in Calabar Municipality, Nigeria.

\section{PROBLEMATIC}

The study area (Calabar Municipality) is gradually becoming unsuitable due to the forces of invasion and succession of commercial activities. The study area had undergone a substantial level of change from the previous uses to commercial use. The commercial activities brought about a lot of inconveniences such as high rent, invasion into people's privacy, traffic congestion, pollution, strain on existing infrastructure and others. Although, these changes are also associated with some positive activities, while its side effects seem to out weight the benefits. Another predominant feature is that buildings that are not fully converted are experiencing partial change of use (Essien, 2008). These types of changes in land requires a small portion of either the veranda or the frontage of the building converted to commercial use or in some cases the building is extended to accommodate the commercial activities, usually in form of kiosks or frontage extension. These changes in land use also create some problems such as traffic congestion, lack of adequate parking space, noise pollution, strain on infrastructure and facilities and housing shortage (Aluko, 2013). However, another problem observed in the study area is that of destroying the building line and major set-backs on the process of conversion or change of uses. Moreover, some houses in the study area are sub-standard and non-conforming or illegal structures causing conflicts and exerting negative influences on other uses around the study area.

Studies have revealed visible signs of ineffectiveness of urban planning regulations and the non-adherence to such regulations by land developers especially zoning ordinances, which is the aftermath of civil unrest and conflicts that have 
occurred in the study area in recent time. There is the problem of inadequate land use planning or the land use plans remaining stagnant over time instead of being dynamic. Also, there is non-enforcement of zoning regulations leading to imbalance in land allocation for various uses (Offiong, 2003).

These problems are also associated with shoddy monitoring of the process of land use change by town planning authorities in the aspect of development control which is attributed to political interference, poor funding, and insufficient technical staff, inadequate equipment and tools, and public resistance (Agbor, Obongha and Ita, 2021). It is on this note that the research made attempts to analyze the pattern of land use change in Calabar Municipality of Cross River State, Nigeria.

\section{AIM AND OBJECTIVES}

The aim of this study is to analyze the pattern of land use change in Calabar Municipality of Cross River State, Nigeria with a view to proposing measure that will guide physical development in the study area.

In order to achieve the aim of this study, the following objectives are formulated:

i. To assess the impact of land use change on physical development in Calabar Municipality.

ii. To examine the population growth and its impact on land use change in the study area.

iii. To identify factors influencing land use change in the study area.

iv. To make recommendations that will guide land use change in the study area.

\section{THE STUDY AREA}

\subsection{Area and Geographical Location}

Calabar Municipality is a local government in Cross River State which is located in the south-south geopolitical region of Nigeria. Calabar Municipality lies between latitude $04^{\circ} 15^{\prime}$ and $5^{\circ} \mathrm{N}$ and longitude $8^{\circ} 25^{\prime} \mathrm{E}$. in the North, the Municipality is bounded by Odukpani Local Government Area in the North-East by the great Kwa River. Its Southern

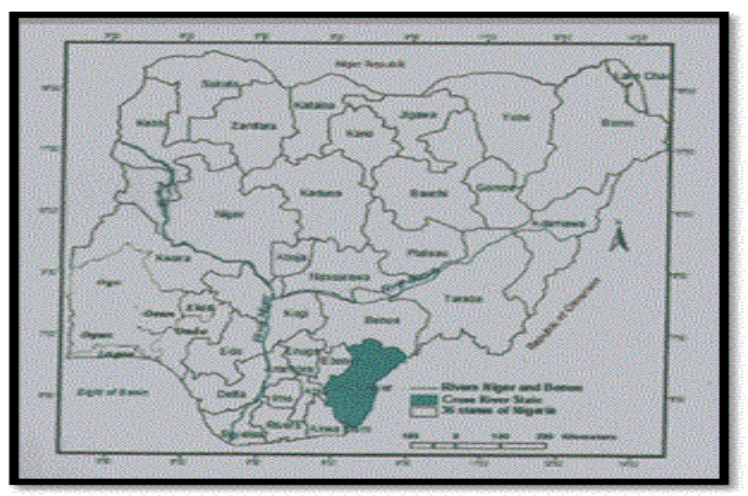

Figure 1: Map of Nigeria showing Cross River shores are bounded by the Calabar River and Calabar Municipality Local Government Area. It has an area of 331.551 square kilometres. Calabar Municipal Government Area plays a dual role. Apart from being the Capital city of Cross river State, it also plays its role as headquarters of the Southern Senatorial District (Udom, 1998).

\subsection{Population}

Municipality is a large urban area with population figure which has increase - steadily over time. As at 1963, Calabar Municipality population stood at 86852 , while during the 1991 population census, the population of Calabar Municipality grew to 203281. It further grew to 179,392 at the 2006 census (National Population Commission 2006).

\subsection{Climate}

Calabar Municipality has a sub-equatorial climate. The temperature of Calabar Municipality is moderately high and has a temperature of $30^{\circ} \mathrm{C}$. Annual rainfall ranges from $250 \mathrm{~mm}$ to $3000 \mathrm{~mm}$ which ushers in the west season which start from the month of March and ends November while the e dry season starts from the month of December and ends in March (Udom, 1998)

\subsection{Vegetation}

The vegetation of Calabar Municipality is by rainforest, saline water, and swamp forest, fresh water swamp forest and grass land. The vegetation of the study area is characterized by mangrove swamp and rainforest, but due to human activities like cutting down of trees, for roads, building of houses, schools and market it has resulted in the depletion of the rainforest. The soil is composed of coastal plain sand which belongs to tertiary deposits. The alluvial deposits are used for construction with light brown and grey colour. According to Cross River Basin Authority (CRBDA, 1982) Cross River State Hydrological Province are grouped into four units namely: basement and intrusive rocks, sandstone, shale and alluvial deposits. The lithology is characterized by an underlying aquifer. The surface and ground water bodies are recharged by high precipitation. The figures 1,2 and 3 shows the study areas in larger and detailed extent.

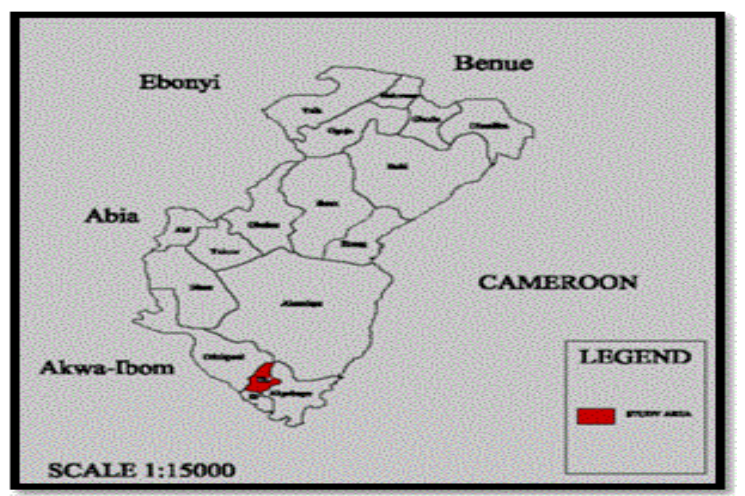

Figure 2: Map of Cross River showing Calabar 


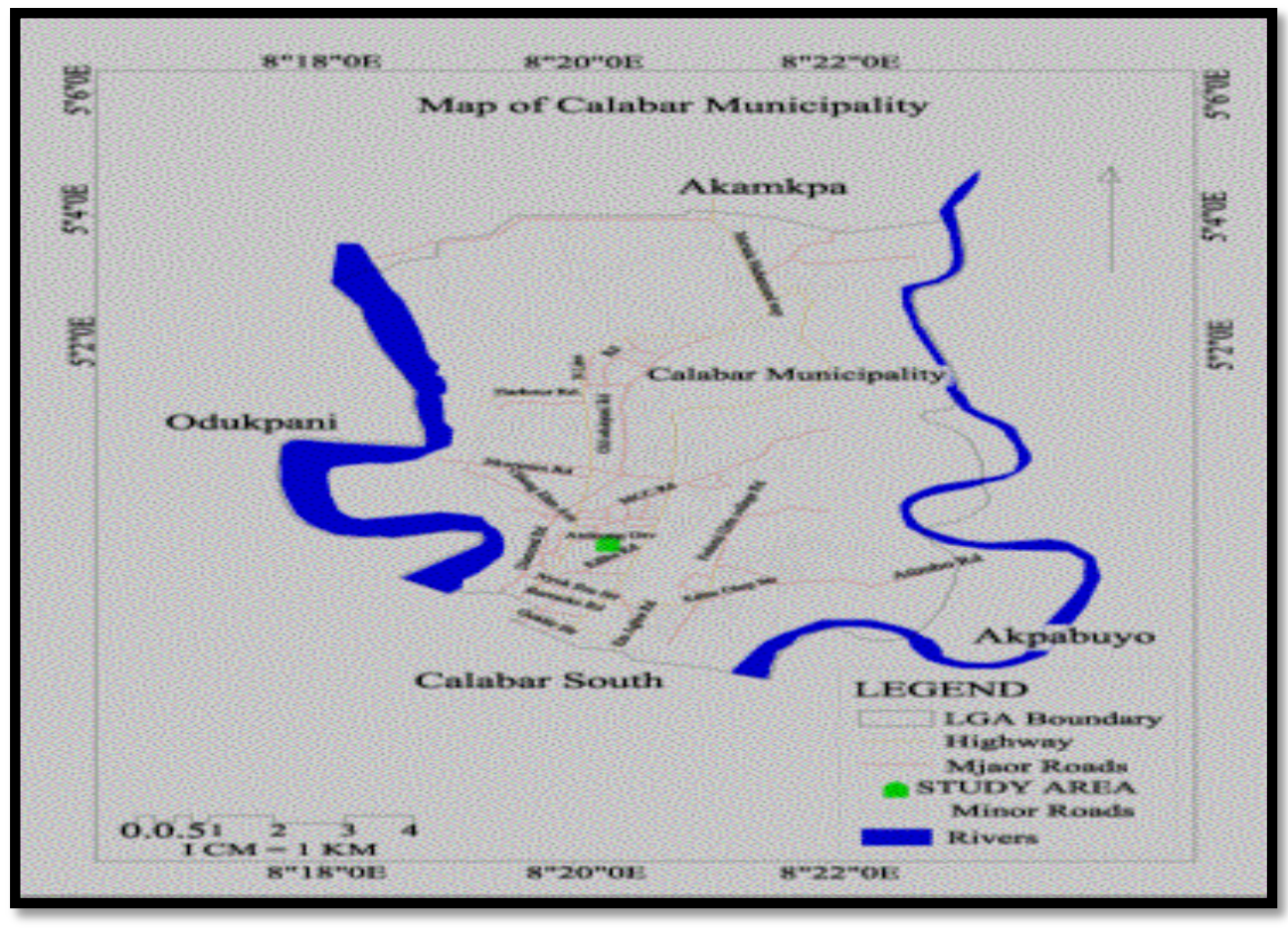

Figure 3: Map of Calabar Municipal showing the study area.

\section{V.}

\section{CONCEPTUAL FRAMEWORK AND LITERATURE REVIEW}

Land use change may involve either a shift to a different use, such as agricultural land changing to residential, or an intensification of the existing use, such as from light to heavy industry. The dual role of human activity in contributing to the causes and experiencing the effects of global change processes brought about by land use changes emphasizes the need for better understanding of the interaction between humans and the environment. This need becomes more imperative as changes in land use become 'more rapid. (TWR, 2000) For example, areas covered by woody vegetation may represent an undisturbed natural shrubland, a forest preserve recovering from a fire, re-growth following tree harvest (forestry), a plantation of immature rubber trees (plantation agriculture), widen agriculture plots that are in between periods, of clearing for a 1nual crop production, or an irrigated tea plantation. Turner (2002) observed that, changes in land cover and in the way people use the land have become recognized over the last 15 years as important global environmental changes in their own tight. From the foregoing it is imperative to say that. Scientific investigation of the causes and consequences of land use change requires an interdisciplinary approach integrating both natural and social scientific methods, which have emerged as the new discipline of land-change science. In order to use land optimally, it is not only necessary to have the information on existing land use, but also the capability to monitor the dynamics of land use resulting from both changing demands of increasing population and natural forces that act to alter and shape the landscape (Lambin, 2003). An improved understanding of historical land-use patterns provides a means to evaluate complex causes and responses in order to better project future trends of human activities on land. Thus, the need to study land use and land use change has become a central component in current strategies in managing natural resources and monitoring environmental changes (Lambin, 2003). Land use describes the use of the land by the people usually with emphasis on the functional role of land in economic activities and man's activities which are directly related to the land. Land use change represents the changes that are occurring over the cover as a result of human modification of its uses. It can also result from human driven natural processes such as climate change. Land use change can alter the terrestrial ecosystem and its ability to perform its provisioning and support service (Abdullah, 2006).

It has the potential to modify the presence and distribution of change in land use can lead to land degradation with potential to significantly exacerbate disaster. The coast of Nigeria is associated with a high intensity of both oil mineral exploration and subsistence farming activities which is leading to changes in the pattern of land use of the area (Yakubu, 2013). Mohammed (2008) noted that expansion in oil exploitation has increased the incidence of oil spills which impact the natural ecosystems. Records from Yakubu (2013), suggest that $77 \%$ of oil spills into the Niger delta environment in Nigeria between 1976 and 1996 was not recovered. The processes involved in oil exploration and transportation in the swamp and mangrove ecosystems degrade the land cover and deplete aquatic fauna in a number of localities. He also asserted that canalization resulting from attempts by oil companies to construct canals to shorten travel time and improve access to production facilities has caused saltwater 
intrusion into freshwater zones, and destroyed ecological systems. The increased accessibility resulting from canalization also aggravates illegal logging activities with adverse environmental consequences. The canals have also provided access for water hyacinth to invade swamps and waterways and so impede navigation. All these factors drive land use change in Nigerian coastline (Lambin, 2003).

Humans have been altering land use since time immemorial through the use of fire to flush out game and, since the advent of plant and animal domestication, through the clearance of patches of land for agriculture and livestock. In the past two centuries the impact of human activities on the land has grown enormously, altering entire landscapes, and ultimately impacting the earth's nutrient and hydrological cycles as well as climate (De Sherbin, 2002). Though humans have been modifying land to obtain food and other essentials for thousands of years, current rates, extents and intensities of land use change are far greater than ever in history, driving unprecedented changes in ecosystems and environmental processes at local, regional and global scales. These land uses exert pressure on the seemingly finite land resources in urban centres, thus land is fast becoming a critical resources, its demand remain a fundamental issue of both academic and policy discourse (Ujoh, 2008).

Land use is the quantitative changes in the area extent (increases or decreases) of a given type of land use. It also includes alteration or modification and conversion from one type of use to another (Briassoulis, 2000). Garba (2008) observed that land use change provides a means of understanding and managing the problems of degradation and shortage of land and water resources. Land use change has been described as the most significant regional anthropogenic disturbance to the environment (Roberts, 2008). In additions, land use change occur when one land use type is converted to another, or is modified, such as a change in agricultural land to residential, or an intensification of existing use, such as from light to heavy industry. Land change is continually influenced by land use due to human cultural, social, and economic activities (Lambin, 2003; Erie and Roberts, 2010).

Land use change over time is an inevitable phenomenon occurring globally due to both temporary and or permanent interest of the inhabitants in a particular area. The phenomenon could be revealed either in a small or large scale but the most interesting and fundamental observation is that change occurs over time in a particular place. It has also been defined as "the arrangements, activities and inputs people undertake in a certain land cover type to produce, change or maintain it" (FAO, 1999). There is an increasing need to be able to precisely describe and classify land change and land uses in order to define sustainable land use systems that are best suited for each place. The driving force for most land use changes is population growth, although there are several other interacting factors involved (Ramankutty, 2002). Competing land uses (agriculture and human settlements mainly) are contributing to the decline of forest and woodland areas and the rising demand for fuel wood and charcoal is also a major cause of deforestation. Settlements represent the most profound human alteration of the natural environment through a spectrum of urban land use activities (Ifatimehin and Ufuah, 2006). Which include, but are not restricted to transportation, commercial, industrial, residential, institutional and recreational land use? Over harvesting, agricultural encroachment and unregulated burning are believed to be contributing to the decline of many species in the wild. There are also incidental impacts on land use from other activities such as forest and lakes damaged by acid rain from fossil fuel combustion, and crops near cities damaged by tropospheric ozone as a result of emissions from automobiles (Meyer, 2003). One of the greatest challenges facing mankind today is land degradation although, the problem is as old as settled agriculture, it extent and impact on human welfare and global environment are now more than before (Lai and Stewart, 2009).

In addition, changes in land use, especially when coupled with climate variability and change, are likely to affect ecosystems and the many important goods and services that they provide to society (Loveland, et al, 2003). Land conversion is the greatest cause of extinction of terrestrial species, of particular concern is deforestation, where logging or burning is followed by the conversion of the land to agriculture or other land uses. Even if forest is left standing, the resulting fragmented landscape typically fails to support many species that previously existed there (Bierregaard, 2000). Land use could be rural or urban, although sometimes. Rural land use is commonly equated to agricultural land use, the On-agricultural land use is also important because it represents the focal areas of activities which directly or indirectly relate to, and whose socio-economic significance depends on the success of agriculture (Ebong, 2002).

In recent times, significant population increase, migration, accelerated socioeconomic activities and increased demands on the landscapes for food and shelter and an increased number of products of man's living environment have led to unparallel changes in land use and modit1cation of rural and urban environments. Ifatimehin and Ufuah ( 2006) and Rimal (2001) asserts that, the change in land occurs even in the absence of human activities through natural processes whereas land use change is the manipulation of land cover by humans for multiple purposes; food, shelter, fuel wood, timber, fodder, medicine, raw materials and recreation. So many socio-economic and environmental factors inter play in land use dynamics. Major consequences of the globally recognized rapid land use changes are; land degradation, agricultural yield depletion, loss of biodiversity and ecosystem functioning. Due to poorly planned human interference, many Africa countries have experience untold environmental degradation and ecological deterioration in the past century, with little or no real solution to alleviate many of these concerns. Adequate information and appropriate technology are limited factors for effective environmental management (Eedy, 2006). The understanding of land use and cover dynamics and interactions with socioeconomic and 
biophysical factors is a necessary tool that will aid the analysis of land-use change across scales.

\section{MATERIALS AND METHODS}

This research adopted the survey design method and by this, the researchers collected several data types such as data on land use change, physical development in the study area, population of the study area, 2011 and 2020 land use cover and planning schemes among others. Both primary secondary sources of data were employed in the research. The total number of neighbourboods in the study area were taken as the sample frame. They Include Ikot Ansa, Ikot Ishie, Ikot Omin, Ikot Eneobong, Ikot Effangha, Nyahaesang, Atimbo/Edim Otop, Akim Qua, Big Qua, Marian/Edibe Qua, Essien Town and Ekorimin. 60\% of this population was selected as the sample size and arrived at the sample population in table 1 .

Table 1: Sampled Population

\begin{tabular}{|c|c|c|c|c|c|}
\hline $\mathbf{S} / \mathbf{N}$ & Neighbourhood & $\begin{array}{c}\text { Existing } \\
\text { populati } \\
\text { on }(2006)\end{array}$ & $\begin{array}{c}\text { Projecte } \\
\text { d } \\
\text { populati } \\
\text { on (2019) }\end{array}$ & Ratio & $\begin{array}{l}\text { Number } \\
\text { Questio } \\
\text { nnaire }\end{array}$ \\
\hline 1. & Ikot Ishie town & 10,351 & 15,206 & 2 & 29 \\
\hline 2. & Ikot Eneobong & 13,135 & 19295 & 5 & 71 \\
\hline 3. & Atimbo/Edim Otop & 28,939 & 41,588 & 7 & 100 \\
\hline 4. & Akim Qua & 11,939 & 16,704 & 4 & 57 \\
\hline 5. & Marian/Edibe Qua & 21,321 & 31,321 & 6 & 86 \\
\hline 6. & Ikot Ansa & 7,534 & 11.067 & 1 & 14 \\
\hline \multirow[t]{2}{*}{7.} & Big Qua Town & 10,219 & 15,800 & 3 & 43 \\
\hline & Total & 93,219 & 120,196 & 28 & 400 \\
\hline
\end{tabular}

Source: Researchers Field Study, 2021

\subsection{Method of Data Collection}

Copies of a questionnaire were administered to respondents selected from the fields of Town Planning, Land Surveying, Architecture, Engineering, Estate Management, Building Construction and many more. The reason for selecting these professionals is basically to produce accurate data since they constitute the built environment and their practice is on land. GIS mapping was also introduce in making a simple comparison of changes in land use cover from 2011 to 2020.

\section{ANALYSIS AND RESULTS}

A total of 400 copies of questionnaire were administered amongst respondents in the study area and 373 copies of questionnaire were filled completely and returned for analysis. The data were analyzed and results presented below.

\subsection{The Impact of Land Use Change on Physical Development}

Table 2 shows the impact of land use change on physical development in the study area. 137 (36.7\%) respondents said that conversion of land use was the impact of land use change on physical development in the study area,
$114(30.6 \%)$ respondents said that land encroachment was the impact of land use change on physical development in the study area, 95 (25.5\%) respondents said that overcrowding of many activities was the impact of land use change on physical development in the study area while $27(7.2 \%)$ respondents fall under others specify respectively.

Table 2: The Impact of Land Use Change on Physical Development

\begin{tabular}{|c|c|c|}
\hline Impact & No. of Respondents & Percentage \\
\hline conversion & 137 & 36.7 \\
\hline Land encroachment & 114 & 30.6 \\
\hline Overcrowding of many activities & 95 & 25.5 \\
\hline Others specify & 27 & 7.2 \\
\hline Total & $\mathbf{3 7 3}$ & $\mathbf{1 0 0 \%}$ \\
\hline
\end{tabular}

Source: Researchers field survey, 2021

\subsection{The Major Problem of Land Use Change}

Table 3 shows the major problem of land use change in the study area. $134(35.9 \%)$ respondents said that overcrowding was major problem of land use change in the study area, $107(28.7 \%)$ respondents said that noise pollution was the major problem of land use change in the study area, $79(21.2 \%)$ respondents said that pressure on existing facilities was the major problem of land use change in the study area while $53(14.2 \%)$ respondents said that congestion was the major problem of land use change respectively.

Table 3: The Major Problem of Land Use Change

\begin{tabular}{|c|c|c|}
\hline Major problem & No. of Respondents & Percentage \\
\hline overcrowding & 134 & 35.9 \\
\hline Noise pollution & 107 & 28.7 \\
\hline Pressure on existing facilities & 79 & 21.2 \\
\hline Congestion & 53 & 14.2 \\
\hline Total & $\mathbf{3 7 3}$ & $\mathbf{1 0 0 \%}$ \\
\hline
\end{tabular}

Source: Researchers field survey, 2021

\subsection{Change of Land Uses}

Table 4 shows the change of land uses in the study area. $123(33.0 \%)$ respondents said that the land was initially used for recreational before change to residential land use in the study area, $115(30.8 \%)$ respondents said that the land was initially used for residential before change to commercial land use in the study area, $99(26.5 \%)$ respondents said that the land was initially used for industrial before change to recreational land use in the study area in the study area while $36(9.7 \%)$ respondents said that the land was initially used for commercial before change to industrial land use in the study area in the study area. 
Table 4: Change of Land Uses

\begin{tabular}{|c|c|c|}
\hline Change of use & Number of Respondents & $\begin{array}{c}\text { Percentage } \\
\mathbf{\%}\end{array}$ \\
\hline Residential & 123 & 33.0 \\
\hline Commercial & 115 & 30.8 \\
\hline Recreational & 99 & 26.5 \\
\hline Industrial & 36 & 9.7 \\
\hline Total & $\mathbf{3 7 3}$ & $\mathbf{1 0 0 \%}$ \\
\hline
\end{tabular}

Source: Researchers field survey, 2021

\subsection{The Impact of Population Growth on Land Use Change}

Table 5 shows the impact of population growth on land use change in the study area. 127 (34.0\%) respondents said that overcrowding was the impact of population structure on land use change in the study area, $130(34.9 \%)$ respondent said that high rent was the impact of population structure on land use change in the study area and $97(26.0 \%)$ respondents said that housing shortage was the impact of population structure on land use change in the study area while $19(5.1 \%)$ respondents fall under others specify respectively.

Table 5: The Impact of Population Groth on Land Use Change

\begin{tabular}{|c|c|c|}
\hline Impact & Number of Respondents & Percentage \\
\hline overcrowding & 127 & 34.0 \\
\hline High rent & 130 & 34.9 \\
\hline Housing shortage & 97 & 26.0 \\
\hline Others specify & 19 & 5.1 \\
\hline Total & $\mathbf{3 7 3}$ & $\mathbf{1 0 0 \%}$ \\
\hline
\end{tabular}

Source: Researchers field survey, 2021

\subsection{Factors Influencing Land Use Change}

Table 6 shows the factors influencing land use change in the study area. $133(35.7 \%)$ respondents said that population was the factors influencing land use change in the study area, 112 (30.0\%) respondent said that road network was the factors influencing land use change in the study area, $74(19.8 \%)$ respondents said that mixed uses was factors influencing land use change in the study area while $54(14.5 \%)$ respondents said that poverty was the factors influencing land use change in the study area.

Table 6: Factors Influencing Land Use Change

\begin{tabular}{|c|c|c|}
\hline Factors & Number of Respondents & Percentage \\
\hline population & 133 & 35.7 \\
\hline Road network & 112 & 30.0 \\
\hline Mixed uses & 74 & 19.8 \\
\hline Poverty & 54 & 14.5 \\
\hline Total & $\mathbf{3 7 3}$ & $\mathbf{1 0 0 \%}$ \\
\hline
\end{tabular}

Source: Researchers field survey, 2021

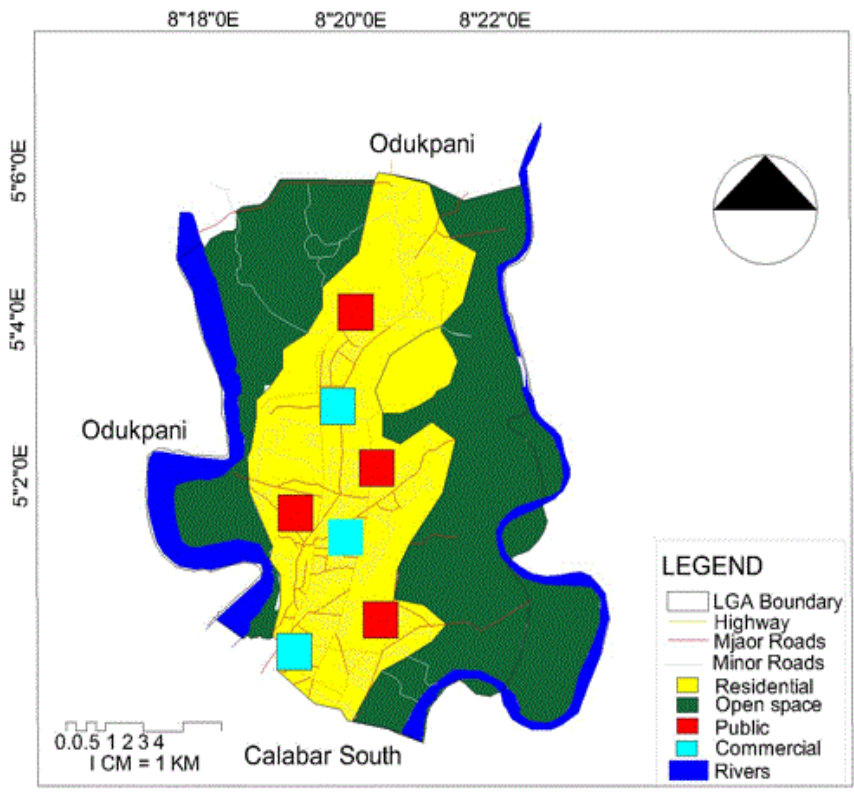

Figure 4: Map of Calabar Municipal showing Land Use Change in 2011

Figure 4 shows GIS analysis of land uses in the year 2011. Where public and institutional areas are shown at heart of the city combine with commercial uses and residential. While agricultural uses were confined at the periphery of the city.

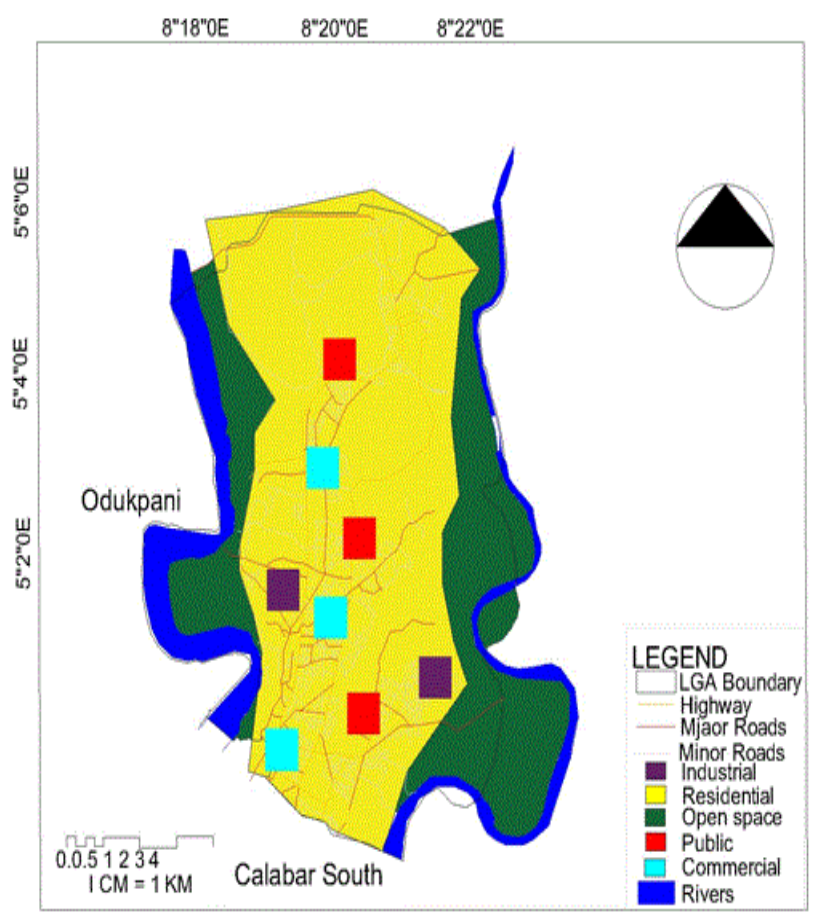

Figure 5: Map of Calabar Municipal showing Land Use Change in 2020

Figure 5 shows that settlement pattern of the city has increased making the size of residential uses to be more than 
what it used to be in 2011. This could be the result of conversion and change of use, while industrial activities have also shown expansion alongside commercial land uses. The implication here is that there has been serious changes in the land use pattern of the study within the periods of 2011 to 2020.

\section{CONCLUSION}

The study examined the analysis of the pattern of land use change in Calabar Municipality, Nigeria. Based on the views of the residents/professionals in land use studies of the study area, and analysis of empirical observations, it has been revealed that land use change affects physical development. The factors that influence changes in land use were also found to include population growth, mixed uses, road network and poverty. The study therefore, recommends as follows: There should be collaboration between planning authorities and government officials in order to reduce conflicts and land use antagonism within the study area and its environs. There should be an awareness programmes to sensitised the citizens on the effect of population growth on infrastructure.

Appropriate and relevant stakeholders of population dynamics should be contacted in order to advise the citizens on the way forward, so as to have a positive change in the environment. There should be more efforts in ensuring proper land use planning and developers should be made to comply with professional standards.

\section{REFERENCES}

[1] Abdullah, J. (2006): Introductory Digital Image Processing - A remote Sensing perspective, Prentice-Hall, N.J, 379p

[2] Abubakar, A. (2002): Remote Sensing and Land Degradation. Nigerian Journal of Remote Sensing, Vol.1 (1), pp 65-72

[3] Agbor, E. A., Obongha, U. E., and Ita, E. E. (2021). Qualitative Survey and evaluation of slum development in Ugep urban, Yakurr Local government Area of Cross River State, Nigeria. International Journal of Advances in Scientific Research and Engineering 7 (11): 97-109.

[4] Agbola, T. (2004) Critical factors determining Rental Value of Residential

[5] Aluko, A. (2013). Factors determining residential rental prices. Asian Economic and Financial Review, 3(1), 39-50. and land cover change: An overview in changes in landuse and land cover:
A global perspective," (eds.) Meyer, W.B. and Turner, B.L.II. Cambridge: Cambridge University Press. 3-10.

[6] Bierregaard, L. (2014) Land Value determination in an emerging market: empirical evidence from China. International Journal of Managerial Finance, 10(2), 180-199.

[7] De Sherbin, N. (2002): Principles relating toremote sensing of the earth from space. $95^{\text {th }}$ Plenary meeting of the General Assembly, Dec. 3, 1986.37.

[8] Ebong, W. (2002) Educational Research: Planning, Conducting and Evaluating Quantitative and Qualitative Research. (4th ed.). Boston, MA: Pearson Education, Inc.

[9] Essien, I. and Samuel, D. (2002): Remote Sensing and Geographic Information Techniques: Veritable Tools for Land Degradation Assessment, American Journal of Geographic Information System 2012, 1(1): 1-6 DOI: 10.5923/j.ajgis.20120101.01

[10] Ifatimehin A. and Ufuah, p. (2006): "Landuse inventory and change detection in the urban - Rural fringes of Ilesa Area." M.Sc Dissertation (unpublished) Department of Geography, ObafemiAwolowo University, Ile-Ife. Pp. 3-39.

[11] Lai, P. and Stewart, Q. (2009) Introduction to Structural Equation Modeling: Issues and Practical Considerations. NCME Instructional Module, Alberta, Canada.

[12] Lambin, N, (2003): Assessment of Impacts and Adaptation to Climate Change: Summary of the Final Report of the AIACC Project. A Global Environment Facility Enabling Activity in the Climate Change Focal Area Project No. GFL-2328 2724-4330

[13] Mabogunje, O. (2006) Land Use Regulations, Compliance and Land Markets in Argentina. Urban Studies, 50(10), 1951-1969.

[14] Mbina, J. (2014). The Impact of Population Growth on Residential Landuse in Calabar, Cross River State. Research on Humanities and Social Sciences, 4(14), 68-74.

[15] Mohammed, F. (2008). Land use change and land degradation in parts of the southwest coast of Nigeria.Afr. J. Ecol., 47 (S1), p3038 ,

[16] Turner, B. (2001). "Change in landuse and land cover change: Challenges for geographers". Geojournal 39(3) Pp 237 - 240.

[17] Ufuah,, M. (2006): Land Degradation and Environmental Change in Ondo State, South-West, Nigeria, An (un-published) PhD thesis , University of Lagos

[18] Ujoh, I. (2008) Comparative Analysis of the Determinants of Residential Land Values. Chinese Business Review, 11(2), 187192.

[19] Yakubu, C. (2013): A Compendium of the Commission's Formation and Activities, Ondo State Oil Producing Area Development Commission, Integrity Press Ltd, Akure.

[20] Zhang, Y. (2006): GIS and remote sensing application in the assessment of change within a coastal environment in the Niger Delta region of Nigeria. Int. Journal Environ. Public Health.3 (1) 98-106. 36. 